\title{
Brand Image and Product Quality on Customer Loyalty (Survey in Cekeran Midun)
}

\author{
Demsi Minar \\ minar_demsi@yahoo.co.id \\ Anindia Safitri \\ Fakultas Ekonomi Universitas Sangga Buana YPKP
}

\begin{abstract}
The purpose of this research is to (1) know customer responses to brand image, product quality, and customer loyalty of Cekeran Midun, (2) know how big the influence of brand image and product quality on customer loyalty are. The methods used are descriptive and verificative analysis. Data were primary and secondary data. Primary data was obtained from questionnaires distributed to 87 customers in Cekeran Midun Cikutra branch, Bandung. Secondary data was obtained from literature texts, journals and other sources that fit the topic of research. The result of analysis and discussion showed that Cekeran Midun Bandung applied brand image in 4 forms namely, recognition, reputation, affinity and domain. Cekeran Midun also implemented 8 forms of product quality i.e. performance, durability, conformance to specifications, features, reliability, aesthetics, perceived quality and serviceability. The influence of brand image and product quality on customer loyalty was $23.32 \%$.
\end{abstract}

Keywords: brand image, product quality, customer loyalty

\section{INTRODUCTION}

In the current global era, business development is increasing rapidly. The increasing of the business world of a country shows a good economic condition. The impact makes the market become more widespread and opportunities are everywhere. However, on the contrary, the competition becomes increasingly tight and unpredictable. This condition requires the company to create a competitive advantage of its business in order to be able to compete on an ongoing basis. Companies that want to grow and gain competitive advantage should be able to provide products in the form of quality goods or services and good service to customers so that customers feel satisfied. Modern marketing today is no longer merely to market quality products, sell products at low prices and put products that are easily reachable to consumers. Competition in the business world increasing sharply. This can be seen from the number of similar products with the same benefits offered in the market that can threaten the continuity of the company's products.

Realizing the increasingly competitive level, Cekeran Midun which is a culinary business do not want to be outdone by its competitors. By choosing a trade mark "ceker" (chicken feet) as a processed menu in the middle of a trend that most culinary oriented on international food but the owner of this Cekeran Midun has a very creative idea by looking at opportunities because a number of people who like this cekeran menu, because chewy, tasty processed chicken feet are commonly found in soup or a bowl of meatball noodles. Cekeran Midun also provides the best quality of products for its customers. This is done to attract the attention of customers in order to always provide a good brand image to Cekeran Midun, so that customers keep their loyalty to the products offered by Cekeran Midun itself.

Brand Image is very important for business in this culinary field for business continuity. Cekeran Midun is highly recommended to pay attention to the quality of its products, so that customers can be loyal to the products offered. Another advantage gained when brand image and quality of product are good. It certainly can be a means of free advertising. Loyal customers of Cekeran Midun will tell others therefore they are interested to try the products that are in Cekeran Midun and become loyal customers as well.

Loyalty affects many marketing activities, one of which is sales. Sales are an important factor in marketing activities that will raise the company's name. At this time, the company is more focused on maintaining old customers and capturing new customers. Moreover, the current global crisis, companies must start a good 
relationship with customers so as to create loyalty that can be achieved through Brand Image and Product Quality.

The success or failure of the marketing mix strategy depends on the consumer's response to the product offered by the company. In general, the consumer decision process of a product occurs when arising from the desire on themselves. This can change with consideration in using one of the elements contained in the marketing mix of brand image products (Enden Novita Dewi, 2013: 40).

A brand needs an image to communicate to audiences, in this case its target market of the values contained therein. For companies, image means public perception of the company's identity. This perception is based on what the community knows about the company in question. Therefore, companies that have the same business field does not necessarily have the same image in the presence of people or consumers. According to Kotler and Keller (2009:260), perceiving Brand Image is the process by which a person chooses, organizes, and interprets information input to create a meaningful picture. According to Tjiptono (2008:49), the definition of brand image is a description of the association and confidence of a consumer to a particular brand.

Kotler and Keller (2009: 419) suggests there are four main things that must be considered in a brand, namely:

1. Recognition, which is the level of familiarity of a brand by consumers, if a brand is not known, then the product with the brand must be sold by relying on a cheap price.

2. Reputation, which is the level or status of a brand, because it is more proven to have a good track record.

3. Affinity, which is an emotional relationship that arises between a brand and its customers. A product with a brand favored by consumers will be easier to sell, and a product that has a high perceived quality will have a good reputation.

4. Domain, concerning the wide scope of a product that is willing to use the brand in question.

Based on the description above, the brand image is the consumer's understanding of the brand as a whole which is not solely determined by how good the name of a product is, but also how to introduce the product in order to become a memory for consumers in forming a perception of a product.

In addition to brand image that can increase customer loyalty to a company, product quality is also a point in improving customer loyalty. Product quality according to Kotler and Keller (2009:49) is the overall feature of a product or service on the ability to satisfy the stated/ implied needs. Meanwhile, according to Lupiyoadi (2013:212), the quality of the product shows the extent to which the product (service) meet the specifications.
According to Tjiptono (2008), quality reflects all dimensions of product offerings that generate benefits for customers. The quality of a product in the form of goods or services is determined through dimensions, including:

1. Performance, related to the basic operating characteristics of a product.

2. Durability, which means how long or the age of the relevant product lasts before the product must be replaced. The greater the frequency of consumer use of the product the greater the power of the product.

3. Conformance to specifications, which is the extent to which the basic operating characteristics of a product meet certain specifications of the consumer or the absence of defects in the product.

4. Features: product characteristics designed to improve the function of the product or increase consumer interest in the product.

5. Reliability: the probability that the product will work satisfactorily or not within a certain period of time. The less likely the occurrence of damage then the product is reliable.

6. Aesthetics, related to how the product looks.

7. Perceived quality, is often the result of the use of measurements made indirectly because there is a possibility that consumers do not understand or lack information on the product concerned.

8. Service ability, including speed and ease of repair, as well as the competence and hospitality of service staff.

Based on several definitions above, product quality is a level of good or bad the consisting of all factors attached to the goods or services. Therefore, the goods have the ability to be used as desired by the consumers of the product. Basically an improvement in product quality requires an improvement that involves everyone in the company to improve better results. Therefore required a high quality product so that customer satisfaction can be fulfilled. It is a big responsibility for the company to ensure its products meet customer needs.

A company is required to find and build a management system that is able to professionally retain its customers, the company is required to be able to cultivate their competitive advantage through creative, innovative and efficient efforts. Thus, they become the choice of many customers who in turn are expected to be loyal consumers. Having consumers are the ultimate goal of all companies.

According to Gremler and Brown in Ali Hasan (2008:83), customer loyalty is a customer who not only repurchases goods and services, but also has a positive commitment and attitude toward the service company, for example by recommending others to buy. Meanwhile, according to Engel, Blackwell, Miniard in Ali Hasan (2008: 84) suggests that customer loyalty 
is a habit of repetition behavior of purchase, linkage and high involvement in choice, and characterized by the search for external information and alternative evaluation.

From these descriptions, customer loyalty is an attitude that encourages behavior to purchase products/services from a company that includes aspects of feelings in it, especially those who buy regularly and repeatedly with high consistency, but not just repurchase goods and services, but also have a commitment and a positive attitude toward the company that offers the product/service.

Several studies have suggested mixed results regarding the effect of brand image and product quality on customer loyalty. Brand image affects customer loyalty expressed by Yudhya (2017) Chao, et.al. (2015); Hung (2008); Wu, et.al. (2011); Ulusua (2011); As well as corporate image is one of the variables that affect customer loyalty (Rai and Srivastava, 2012). While other research suggests that brand image affects customer loyalty if through intervening variable of customer satisfaction (Zhang, 2015 and Tu, et al., 2012). While research by Thakur and Singh shows brand image has a good effect on customer satisfaction and customer loyalty. This research will be conducted to find out:

1) The brand image, product quality, and customer loyalty at Cekeran Midun Cikutra Branch,

2) The influence of brand image and product quality on customer loyalty at Cekeran Midun Cikutra Branch.

\section{METHODS}

The method used in this research was descriptive associative. Analytical methods used were (1) descriptive method and (2) multiple linear regression analysis method. In descriptive method, the data will be classified referred to the provisions proposed by Suharsimi Arikunto (2002: 354-356) whose range of scores are searched with the following formula:

$$
\text { Score Range }=\frac{\text { Highest Score }- \text { Lowest Score }}{\text { Total Classification }}
$$

Information:

Highest score $=$ number of respondents $\mathrm{x}$ highest weight $\mathrm{x}$ number of items.

Lowest score $=$ number of respondents $\mathrm{x}$ lowest weight $\mathrm{x}$ number of items.

Multiple regression analysis was used to determine the effect of Brand Image and Product Quality on customer loyalty to know the effect of the used calculation coefficient of determination.

\section{RESULTS}

To be able to create a good product image the company needs to apply four main things that must be considered in a brand: Recognition, Reputation, Affinity and Domain.

The results of scoring in Table 1 showed that in total, Brand Image is in the category of "agree" with the score of 2,649. The total score of Brand Image is in the range between 2,366.4 - 2,922.2 which falls in the "agree" category, as the four dimensions that make up the brand image which are Recognition, Reputation, Affinity and Domain, reach the average in the "agree" category. This fact gave an indication that the community or the customers agreed with the brand image created by Cekeran Midun or even more enhanced of the four dimensions of this brand image. The lowest dimension were affinity and domain, meaning the manager needed to improve the life style, the level of equality between the customer's perception with the product offered, the scope of product use and similar product type with the brand of Cekeran Midun.

The quality of a product either in the form of goods or services is determined through its dimensions. Product quality dimensions are Performance, Durability, Conformance to specifications, Features, Reliability, Aesthetics, Perceived Quality and Serviceability.

The results of scoring in Table 2 showed that the total Product Quality is in the category of "agree" with the score of 5,567. The total score of Product Quality is in the range of classification criteria between 4,694.4 - 5,826.2 which falls in the "agree" category, as the eight dimensions that make up the Product Quality which are Performance, Durability, Conformance to specifications, Features, Reliability, Aesthetics, Perceived Quality and Serviceability reach the average in the "agree" category. This fact gave an indication that the community or the customers agreed with the quality of products offered by Cekeran Midun or even more enhanced of the eight dimensions. The lowest indicator was the taste and nutritional content of Cekeran Midun. Managers needed to improve the taste and nutritional content of their processed products, so that the quality of the products increased.

A company is required to find and build a management system that is able to professionally retain its customers. The company itself is required to be able to cultivate their competitive advantage through creative, innovative and efficient efforts. Thus, they become the choice of many customers who in turn are expected to be loyal consumers. Having consumers are the ultimate goal of all companies. 
The results of scoring in Table 3 showed that in total, Customer loyalty is in the category of "agree" with the score of 1,743 . The total score of Product Quality score is in the range between 1,479 - 1,826 which falls within the "agree" category, as the five indicators reach the average in the "agree" category. This fact gave an indication that the public or the customers agreed to be loyal customers at Cekeran Midun or even further enhanced each of its indicators to increase the number of loyal customers to Cekeran Midun. The lowest dimensions score were the creation of prospects and buying outside the product and service lines. This are ingredients for managers of Cekeran Midun to improve, for example by innovating in taste, adding nutritional content, as well as developing new products that follow the lifestyles and anticipate the development of competitors.

Multiple linear regression equation was used to find out how far the influence of brand imgae and product quality of Cekeran Midun to customer loyalty.

Based on Table 4 then it is known that multiple linear regression equation is:

$$
\mathrm{Y}=5,093+0,030 \mathrm{X}_{1}+0,200 \mathrm{X}_{2}
$$

The correlation between Brand Image, Product Quality and Customer Loyalty is 0.483 and is in the range of $0.40-0.599$. It has moderate relationship. Partial correlation is shown in Table 5.

A. $\mathrm{X}_{1}$ towards $\mathrm{Y}$ is $0.268 *$ that means the brand image has a low level of relationship to customer loyalty of Cekeran Midun

B. $\mathrm{X} 2$ towards $\mathrm{Y}$ is 0.482 that means that the product quality has a moderate level of relationship to customer loyalty of Cekeran Midun.

The coefficient of determination was used to determine the effect of Brand Image and Product Quality on Customer Loyalty (Table 6).

Based on Table 6, the determination coefficient is $23.32 \%$. This is the role of Brand image and product quality on customer loyalty. While the remaining is $76.68 \%$ influenced by other variables not examined in this study. For example, the high competition of similar products, different customer tastes, low customer buying interest.

To know whether there was a significant effect of brand image and product quality on customer loyalty shown in Table 7.

Based on Table 7, it is obtained: (a) The level of Brand Image offered by Cekeran Midun had no significant effect on customer loyalty, (b) Product Quality offered by Cekeran Midun had significant influence on customer loyalty because tcount $=4,208$.
Brand image had no direct effect on customer loyalty. This result was contrary to Yudhya's research (2017); Chao, et.al. (2015); Hung (2008); Wu, et.al. (2011); Ulusua (2011), because it was suspected that there was a variable between customer satisfaction as stated by Zhang (2015) that brand image exerts no direct influence on customer loyalty, but it can impact on customer loyalty via customer satisfaction. So does Tu, et. al. (2012), corporate brand image significantly affects customer satisfaction and customer loyalty, and customer satisfaction has strong impact on customer loyalty.

Product quality had a significant effect on customer loyalty, this was in accordance with the results of Halim's research, et.al. (2014); Thakur and Singh (2012); Jahanshahi, et.al. (2011). This meant that customer loyalty could increase as product quality increased. The quality of the product that needed to be improved was from the indicator of taste and nutrient content.

$F$ test was used to test the simultaneous effect of brand image and product quality on customer loyalty (Table 9).

Based on Table 9 it can be seen that $\mathrm{F}_{\text {count }}>\mathrm{F}_{\text {table }}$ is $12.791>3.10$, so $\mathrm{H}_{0}$ is rejected and $\mathrm{H}_{1}$ is accepted. This meant that brand image and product quality together had a significant effect on customer loyalty. These results suggested that managers could increase customer loyalty through improved brand image and product quality.

\section{CONCLUSION}

Based on the research results, several conclusions can be drawn as follows:

1. Customer feedbacks about brand image, product quality, and customer loyalty of Cekeran Midun were at good level. The lowest dimensions of brand image were affinity and domain, which included life style, the level of equality between customer perception with the product offered, product usage coverage and similar product type with the brand of Cekeran Midun. The lowest indicators of product quality were the level of taste and nutrient content. The lowest dimensions of loyalty were the creation of prospects and buying outside the product and service lines. It is important for managers of Cekeran Midun to improve some ingredients: for example, innovating in taste, adding nutritional content, and also developing new products that follow lifestyle and anticipate the development of competitors.

2. Brand Image and Product Quality simultaneously influenced Customer Loyalty of Cekeran Midun. Brand image had no significant effect on customer loyalty, while product quality had significant effect. It means that improving product quality will increase customer loyalty. 


\section{REFERENCES}

Ali Hasan. 2008. Marketing. PT. Buku Kita. Jakarta. Arikunto, Suharsimi. 2002. Metode Penelitian. PT. Ghalia Indonesia, Jakarta.

Chao, Ren-Fang; Tai-Chi Wu; Wei-Ti Yen. 2015. The Influence of Service Quality, Brand Image, and Customer Satisfaction on Customer Loyalty for Private Karaoke Roomsin Taiwan. The Journal of Global Business Management. Vol. 11. Number 1. April.

Dewi, Enden Novita. 2013. Pengaruh Brand Image terhadap Proses Pengambilan Keputusan Mahasiswa Alih Program di Universitas Widyatama Bandung (Studi Kasus pada Mahasiswa Alih Program Fakultas Bisnis dan Manajemen. Repository.widyatama.ac.id

Halim, Peter; Bambang Swasto; Djamhur Hamid; M. Riza Firdaus. 2014. The Influence of Product Quality, Brand Image, and Quality of Service to Customer Trust and Implication on Customer Loyalty (Survey on Customer Brand Sharp Electronics Product at the South Kalimantan Province). European Journal of Business and Management. Vol. 6 No. 29.

Hung, C. H. 2008. The Effect of Brand Image on Public Relation Perceptions and Customer Loyalty. International Journal of Management. 25 (2). 237 $-246$.

Jahanshahi, Asghar Afshar; Mohammad Ali Hajizadeh Gashti; Seyed Abbas Midarmadi; Khaled Nawaser. 2011. Study the Effects of Customer Service and Product Quality on Customer Satisfaction and Loyalty. International Journal of Humanities and Social Science. Vol. 1 No. 7, $253-260$.

Lupiyoadi, Rambat. 2013. Manajemen Pemasaran Jasa. Salemba Empat. Jakarta.
Kotler, Philip dan Keller Kevin Lane. 2009. Manajemen Pemasaran. Edisi 13.

Rai, Alok Kumar and Medha Srivastava. 2012. Customer Loyalty Attributes: A Perspective. NMIMS Management Review. Volume XXII October-November.

Thakur, Satendra and A.P. Singh. 2012. Brand Image, Customer Satisfaction, and Loyalty Intention: A Stdy in the Context of Cosmetic Product among the People of Central India. EXCEL International Journal of Multidiciplinary Management Studies. Vol. 2. Issue 5. May.

Tjiptono, Fandy. 2008. Strategi Pemasaran. Andi.

Ulusua, Y. 2011. Effects of Branding Image on Brand Trust. Journal of Yasar University. 6 (24). 3932 -3950 .

Tu, Yu-Te; Chin-Mei Wang; Hsiao-Chien Chang. 2012. Corporate Brand Image and Customer Satisfaction on Loyalty: An Empirical Study of Starbucks Coffee in Taiwan. Journal of Social and development Sciences. Vol. 3, No. 1, pp 24 -32 . January.

Wu, P. C. ; Yeh, G. Y. Y. and Hsiao, C. R. 2014. The Effect of Store Image and Service Quality on Brand Image and Purchase Interntioan fo Private Label Brands. Australasian Marketing Journal. 19 (1). $30-39$.

Yudhya, Thomas Budhyawan. 2017. The Effects of Service Quality and Brand Image toward Consumer Loyalty (Study at consumers of Smartphone OPPO in Bandung, Indonesia). Proceeding of The International Conference on E-Business, Marketing and Branding (IC17 Hong Kong Conference). January.

Zhang, Yi. 2015. The Impact of Brand Image on Consumer Behavior: A Literature Review. Open Journal of Business Management. Published Online January 2015 in Scientific Research Publishing. 


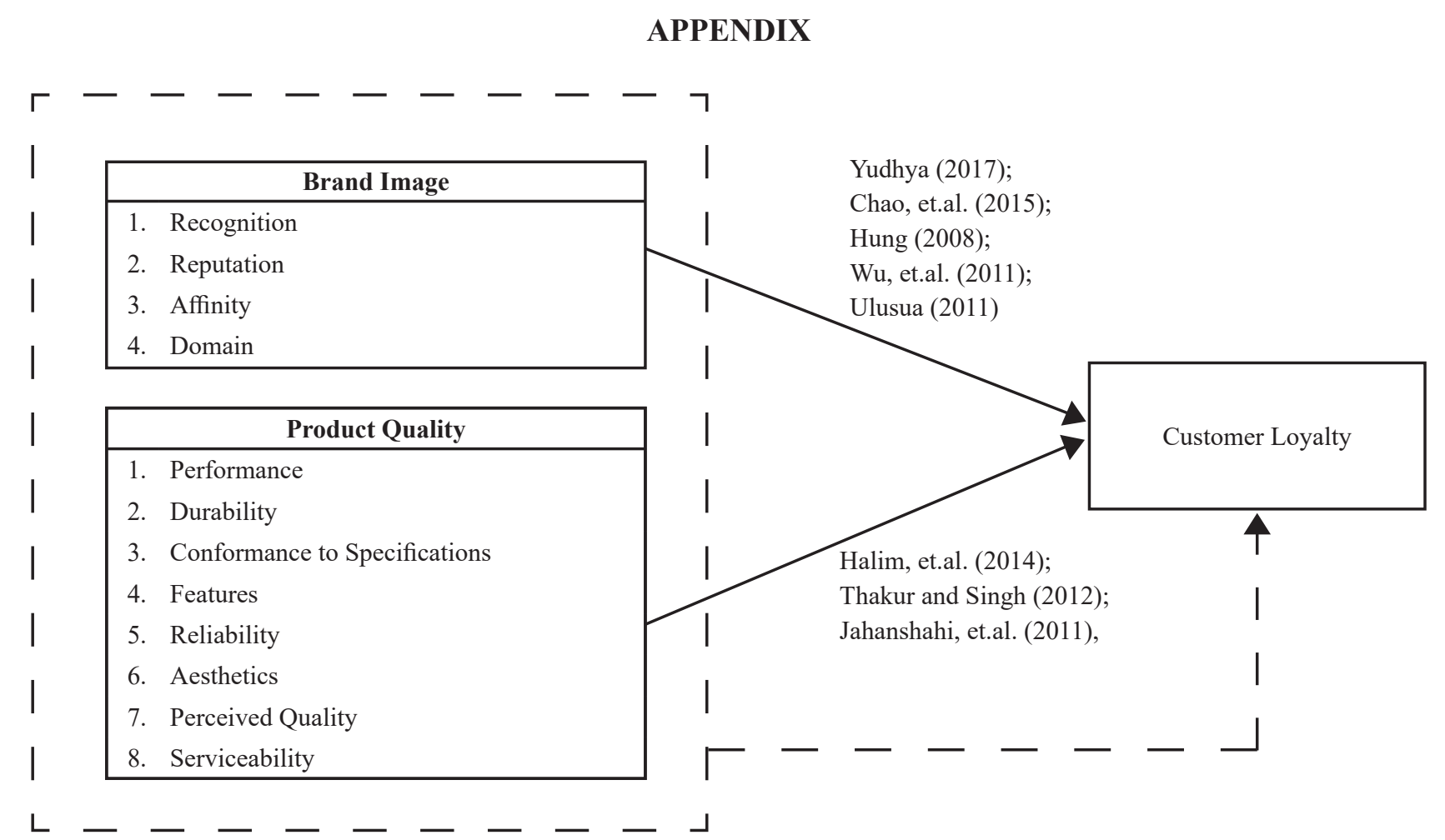

Figure 1. Research Paradigm

Table 1. Level of Customer's Statement on Brand Image

\begin{tabular}{|c|c|c|c|}
\hline No & Dimension & Indicator & Total Score \\
\hline \multirow{3}{*}{1} & & - Level of introduction to the brand product of Cekeran Midun & 324 \\
\hline & Recognition & - $\quad$ Place Design & 354 \\
\hline & & Total Recognation & 678 \\
\hline \multirow{3}{*}{2} & & - Customer's perception of the taste of Cekeran Midun products & 336 \\
\hline & Reputation & - Level of customer's confidence in Cekeran Midun & 335 \\
\hline & & Total Reputation & 671 \\
\hline \multirow{3}{*}{3} & & - $\quad$ Life style & 335 \\
\hline & Affinity & $\begin{array}{l}\text { Level of equality between customer's perceptions and those offered by brand products } \\
\text { of Cekeran Midun }\end{array}$ & 304 \\
\hline & & Total Affinity & 639 \\
\hline \multirow{4}{*}{4} & & - $\quad$ Product use scope & 335 \\
\hline & Domain & - Types of products using similar products under the name of Cekeran Midun & 326 \\
\hline & & Total Domain & 661 \\
\hline & & Total Score of Customer's Statement on Brand Image & 2649 \\
\hline
\end{tabular}


Table 2. Level of Customer's Statement on Product Quality

\begin{tabular}{|c|c|c|c|}
\hline No & Dimension & Indicator & Total Score \\
\hline \multirow{3}{*}{1} & \multirow{3}{*}{ Performance } & - Taste level of Cekeran Midun products & 312 \\
\hline & & - Level of nutritional content of Cekeran Midun products & 317 \\
\hline & & Total & 629 \\
\hline \multirow{2}{*}{2} & \multirow{2}{*}{ Durability } & - Durability level of Cekeran Midun Products & 369 \\
\hline & & Total & 369 \\
\hline \multirow{3}{*}{3} & \multirow{3}{*}{$\begin{array}{l}\text { Conformance to } \\
\text { specifications }\end{array}$} & - Level of product display appropriateness & 374 \\
\hline & & - Level of compliance of quality standards & 365 \\
\hline & & Total & 739 \\
\hline \multirow{4}{*}{4} & \multirow{4}{*}{ Features } & - Diversity level of Cekeran Midun products & 331 \\
\hline & & - Interest level of Cekeran Midun products & 343 \\
\hline & & - Level of clarity of information provided about Cekeran Midun products & 357 \\
\hline & & Total & 1031 \\
\hline \multirow{3}{*}{5} & \multirow{3}{*}{ Reliability } & - Level of product physical condition and appearance when purchased & 353 \\
\hline & & - Possible level of product and display malfunction & 361 \\
\hline & & Total & 714 \\
\hline \multirow{3}{*}{6} & \multirow{3}{*}{ Aesthetics } & - $\quad$ Appetizing scent level of the product & 306 \\
\hline & & - Attractive product display level & 322 \\
\hline & & Total & 628 \\
\hline \multirow{3}{*}{7} & \multirow{3}{*}{ Perceived quality } & - Impression of good quality from product price aspect & 374 \\
\hline & & - Impression of good quality from product appearance and taste aspect & 388 \\
\hline & & Total & 762 \\
\hline \multirow{3}{*}{8} & \multirow{3}{*}{ Serviceability } & - $\quad$ Cekeran Midun's employees' friendly level & 371 \\
\hline & & - Level of facilities offered by Cekeran Midun & 324 \\
\hline & & Total & 695 \\
\hline & & Score of Customer's Statement on Product Quality & 5567 \\
\hline
\end{tabular}

Table 3. Level of Customer's Statement on Customer Loyalty

\begin{tabular}{|c|c|c|}
\hline No & Dimension & Score \\
\hline 1 & Purchase regularly & 359 \\
\hline 2 & Rejection of competitors' products & 352 \\
\hline 3 & Buy outside the product or service line & 337 \\
\hline 4 & Creation of prospects & 335 \\
\hline 5 & Recommend to others & 360 \\
\hline \multicolumn{2}{|r|}{$\begin{array}{c}\text { Total Score of Customer's Statement on Customer Loyalty } \\
\end{array}$} & 1743 \\
\hline
\end{tabular}

Table 4. Multiple Regression Linear

\begin{tabular}{|c|c|c|c|c|c|c|c|c|c|}
\hline \multicolumn{2}{|c|}{ Model } & \multicolumn{2}{|c|}{$\begin{array}{c}\text { Unstandardized } \\
\text { Coefficients }\end{array}$} & \multirow{2}{*}{$\begin{array}{c}\text { Standardized } \\
\text { Coefficients }\end{array}$} & \multirow[t]{2}{*}{$\mathrm{T}$} & \multirow[t]{2}{*}{ Sig. } & \multicolumn{3}{|c|}{ Correlations } \\
\hline & & $\mathrm{B}$ & Std. Error & & & & Zero-order & Partial & Part \\
\hline \multirow[t]{3}{*}{1} & (Constant) & 5.093 & 2.223 & & 2.291 & .024 & & & \\
\hline & Brand Image & .030 & .081 & .041 & .371 & .712 & .268 & .040 & .035 \\
\hline & Product Quality & .200 & .048 & .462 & 4.208 & .000 & .482 & .417 & .402 \\
\hline
\end{tabular}

a. Dependent Variable: Customer Loyalty 
Table 5. Partial Correlation

\begin{tabular}{llccc}
\hline & & Brand Image & Product Quality & Customer Loyalty \\
\hline Brand Image & Pearson Correlation & 1 & $.492^{* *}$ & $.268^{*}$ \\
& Sig. (2-tailed) & & .000 & .012 \\
& $\mathrm{~N}$ & 87 & 87 & 87 \\
Product Quality & Pearson Correlation & $.492^{* *}$ & 1 & $.482^{* *}$ \\
& Sig. (2-tailed) & .000 & & .000 \\
Customer Loyalty & $\mathrm{N}$ & 87 & 87 & 87 \\
& Pearson Correlation & $.268^{*}$ & $.482^{* *}$ & .000 \\
& Sig. (2-tailed) & .012 & 87 & 87 \\
\hline
\end{tabular}

**. Correlation is significant at the 0.01 level (2-tailed).

*. Correlation is significant at the 0.05 level (2-tailed).

Table 6. Coefficient of Determination

Model Summary ${ }^{\mathrm{b}}$

\begin{tabular}{cccccc}
\hline Model & $\mathrm{R}$ & R Square & Adjusted R Square & Std. Error of the Estimate & Durbin-Watson \\
\hline 1 & $.483^{\mathrm{a}}$ & .233 & .215 & 2.612 & 1.509 \\
\hline
\end{tabular}

a. Predictors: (Constant), Product Quality, Brand Image

b. Dependent Variable: Customer Loyalty

Table 7. t Test

\begin{tabular}{|c|c|c|c|c|c|c|c|c|c|}
\hline \multicolumn{2}{|c|}{ Model } & \multicolumn{2}{|c|}{$\begin{array}{c}\text { Unstandardized } \\
\text { Coefficients }\end{array}$} & \multirow{2}{*}{$\begin{array}{c}\text { Standardized } \\
\text { Coefficients }\end{array}$} & \multirow[t]{2}{*}{$\mathrm{T}$} & \multirow[t]{2}{*}{ Sig. } & \multicolumn{3}{|c|}{ Correlations } \\
\hline & & $\mathrm{B}$ & Std. Error & & & & Zero-order & Partial & Part \\
\hline \multirow[t]{3}{*}{1} & (Constant) & 5.093 & 2.223 & & 2.291 & .024 & & & \\
\hline & Brand Image & .030 & .081 & .041 & .371 & .712 & .268 & .040 & .035 \\
\hline & Product Quality & .200 & .048 & .462 & 4.208 & .000 & .482 & .417 & .402 \\
\hline
\end{tabular}

a. Dependent Variable: Customer Loyalty

Table 9. F Test

\begin{tabular}{llccccc}
\hline Model & & Sum of Squares & df & Mean Square & F & Sig. \\
\hline 1 & Regression & 174,564 & 2 & 87.282 & 12.791 & $.000^{\mathrm{a}}$ \\
& Residual & 573,193 & 84 & 6.824 & & \\
& Total & 747,757 & 86 & & & \\
\hline
\end{tabular}

a. Predictors: (Constant), Product Quality, Brand Image

b. Dependent Variable: Customer Loyalty 